\title{
Assessment of Soil Erosion with RUSLE 3D and USPED in the Nekor Watershed (Northern Morocco)
}

\author{
Nassima Arrebei ${ }^{*}$, Mohamed Sabir ${ }^{2}$, Mustapha Naimi'1, Mohamed Chikhaoui ${ }^{1}$, Damien Raclot ${ }^{1,3}$ \\ ${ }^{1}$ Institut Agronomiqueet Vétérinaire Hassan II, Rabat, Maroc \\ ${ }^{2}$ École Nationale Forestière d'Ingénieurs, Salé, Morocco \\ ${ }^{3}$ LISAH, University Montpellier, IRD, Montpellier, France \\ Email: *nassimagrn@gmail.com
}

How to cite this paper: Arrebei, N., Sabir, M., Naimi, M., Chikhaoui, M. and Raclot, D. (2020) Assessment of Soil Erosion with RUSLE 3D and USPED in the Nekor Watershed (Northern Morocco). Open Journal of Soil Science, 10, 631-642.

https://doi.org/10.4236/ojss.2020.1012031

Received: October 26, 2020

Accepted: December 28, 2020

Published: December 31, 2020

Copyright $\odot 2020$ by author(s) and Scientific Research Publishing Inc. This work is licensed under the Creative Commons Attribution International License (CC BY 4.0).

http://creativecommons.org/licenses/by/4.0/

c) (i) Open Access

\begin{abstract}
Over the last decades, estimation of soil erosion using empirical models has long been an active research topic, especially because they are useful to establish watershed management plans. Nevertheless, their application over large areas in a data-scarce Mediterranean region is still a challenge given the furrowed and steep nature of landscapes as well as the aggressiveness of the semi-arid climate. The main purpose of this research was to identify the spatial patterns of erosion and deposition in Nekor river basin (Northern Morocco) using two models: the Revised Universal Soil Loss Equation for Complex Terrain (RUSLE3D) and the Unit Stream Power-based Erosion Deposition (USPED). The two models were evaluated using existing annual soil loss rate measurements. As a result of the RUSLE3D application, about the $73 \%$ of the Nekor basin ranges between moderate and extreme risks of erosion, while according to USPED estimation, only $50 \%$ of the basin ranges between moderate and extreme risks of erosion. The analysis shows that the mean annual soil erosion rate for both models ranges between 60 and $65 \mathrm{t} \cdot \mathrm{ha}^{-1} \cdot \mathrm{year}^{-1}$ while the mean annual deposition rate is $38 \mathrm{t} \cdot \mathrm{ha}^{-1} \cdot \mathrm{year}^{-1}$. The current results confirmed those coming from previous soil erosion studies, which estimated annual soil loss rates in Nekor river basin between 50 and $70 \mathrm{t} \cdot \mathrm{ha}^{-1} \cdot \mathrm{year}^{-1}$. This study also provided valuable guidance on where to implement soil protection measures.
\end{abstract}

\section{Keywords}

Rif Mountain, Nekor Watershed, Soil Erosion, RUSLE3D, USPED, Remote Sensing, GIS 


\section{Introduction}

In Morocco, soil erosion hampers the development of sustainable agriculture. According to the National Development Plan of watersheds [1] erosion affects a large part of the territory: a total area of large basins (about 20 million ha), the risk of erosion surfaces represents $75 \%$. The most affected area by water erosion is the northern part of Morocco, especially the Rif which covers only $6 \%$ of the total area of the country, while $60 \%$ of soil losses are from this area [2] due to anthropogenic pressure and the intrinsic vulnerability of the environment.

Modelling soil erosion can provide a quantitative and consistent estimation of the phenomenon under various conditions. A wide range of models exists for use in simulating soil erosion. The assessment of soil erosion over large areas typically involves the use of empirical models such as the USLE [3], the MUSLE [4], the RUSLE [5], the RUSLE3D [6], the USPED [7] [8] [9] or more process-based models such as the PESERA or STREAM [10] a physically-based models designed to predict hill slope erosion and transport of sediment at a range of small catchment to national scale with land cover, soil, topography, and climate data [11]. They also could be used to investigate the impact of climate change on the effectiveness of conservation measures. However, these models differ greatly in terms of complexity, processes considered and data required for model calibration and model use [12].

In Morocco, the lack of reliable and valid field measurements, e.g. the doubtful quality of sediment flow measurements (increases the improper validation issue), poor disposal of soil data (soil maps unavailability or limitation) and climatic data (measurement stations with several non-functioning periods and no spatially and temporarily enough detailed data), beside complications regarding their acquirement, causes significant limitations to the application of most comprehensive models. This frequently leads to selecting empirical models that essentially meet the criterion of low data requirements (along with computational speed, ease of use, low implementation cost, etc.), providing moreover a good basis in terms of a preliminary approximation.

The choice lies under the conjecture that such models will probably perform better than the comprehensive ones, as the use/calibration of all of the factors involved unavoidably induces errors that may not be less than those of a simple and lumped approach.

Considering the above, the aim of this study was to quantify the soil erosion rates in order to identify priority areas for soil protection in the Nekor river basin, a highly erosion prone watershed in North Morocco (Figure 1). This study presents the soil erosion and deposition rates derived from RUSLE3D and USPED models. The reliability and predictive ability of these two models in quantifying soil erosion and deposition rates at watershed scale were assessed using existing measurements proposed by Amil and Lahlou in the nineties [13] [14].

\section{Study Area}

The Nekor watershed is located in the mountains of the central Mediterranean 


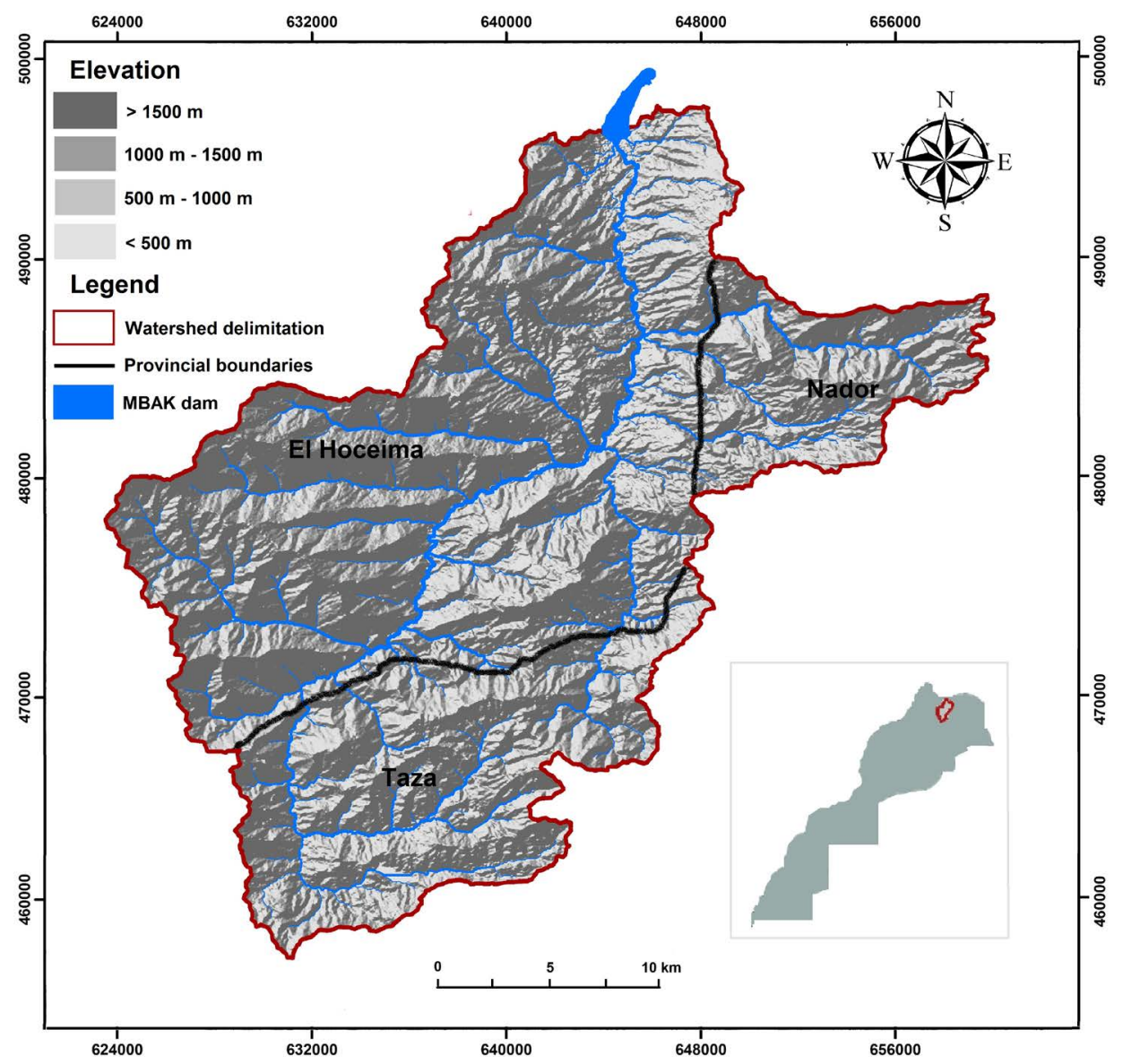

Figure 1. Map showing the elevation of the Nekor watershed.

Rif in northern Morocco. It is a watershed of $780 \mathrm{~km}^{2}$ upstream of the Mohamed Ben Abdelkrim Al Khatabi (MBAK) reservoir built in 1981 with an initial storage capacity of 43.3 million $\mathrm{m}^{3}$ to supply several irrigated perimeters as well as the city of $\mathrm{Al}$ Hoceima with drinking water. The climate is Mediterranean semi-arid to arid; cold and wet in winter and hot and dry in summer. Average monthly temperatures range from $7^{\circ} \mathrm{C}$ (in January) to $28^{\circ} \mathrm{C}$ (in August), but can drop as low as $0^{\circ} \mathrm{C}$ in mountain peaks. Precipitation $(340 \mathrm{~mm} /$ year near $\mathrm{Al} \mathrm{Ho}$ ceima) consists of stormy precipitation concentrated between October and May, and sometimes in summer under the influence of the relief.

The dominant relief is mountainous. The altitudes range from $100 \mathrm{~m}$ in the MBAK reservoir to 2009 meters at Mount "Jbel Azrou Akechou", with an average altitude of about $1500 \mathrm{~m}$. The slopes are of variable exposures, and a high proportion of watershed area has slope gradients greater than $60 \%$. The overall slope index is $20.7 \mathrm{~m} / \mathrm{km}$ throughout the watershed. This index is higher in the banks of the left bank than for those of the right bank.

The Nékor basin is characterized by sedimentary geological formations of the schist and marno-schist type, tender, fractured, without consistency. The dominant soils are unmature soils and minerals soils constituted by debris of weathering of the substrates. They are shallow and very poor in organic matter 
$(<1 \%)$. The textures are clayey to clayey-silty with a few small cases of sandy-clayey. These soils are very sensitive to water erosion.

Overall, the watershed has very little vegetation. Previous generations cleared natural vegetation to cultivate the land (cereals). Much of this land was abandoned in the 1970s for extensive pasture because of the emigration of men to Europe. Currently, we note the dominance of degraded rangelands and bare soils. The scrub and forest plantations (pines, Eucalyptus) occupy the upstream and central part of the basin. However, farmers maintain subsistence farming based on cereal crops (wheat), fodder crops (corn, alfalfa) and fruit trees (olive trees) on irrigable alluvial terraces.

The hydrographic network is very dense, consisting essentially of dynamic torrents. The Nekor bed is typical of semiarid zones, a large major bed furrowed by a deep and unstable minor bed. Narrow alluvial terraces run along the wadis beds in very deep valleys.

Despite the low rainfall, the basin is subject to significant floods due to stormy, intense and irregular rains and very favorable environment to runoff (bare soil dominance, rugged relief, and degraded plant cover). The flow discharge of the Nekor wadi is very intermittent. The average annual number of floods is 3 to 4 and does not exceed 10 per year.

Specific degradation rates of more than $7000 \mathrm{t} \cdot \mathrm{km}^{-2} \cdot \mathrm{year}^{-1}$ have been recorded [13]. The silting up of the MBAK reservoir is spectacular since $73.9 \%$ of its storage capacity was lost in 33 years, between 1981 (43.3 million $\mathrm{m}^{3}$ ) and 2013 (11.3 million $\mathrm{m}^{3}$ ). As a result of this siltation, there is a significant risk of water scarcity, which threatens the sustainability of human activity in this sector.

\section{Method and Materials}

The general methodology adopted as shown in Figure 2 was based on selecting two different prediction models to simulate soil erosion and sediment yield: the Revised Universal Soil Loss Equation for Complex Terrain (RUSLE3D) and the Unit Stream Power-based Erosion Deposition (USPED). These two models used similar input datasets within GIS: a digital terrain model, products derived from satellite remote sensing, lithologic maps and rainfall data.

In general words, RUSLE3D is a detachment capacity model while USPED is a transport capacity model and it has the ability to identify the spatial distribution of both erosion and deposition rates for a constant state of overland flow with uniform rainfall-excess conditions.

The Universal Soil Loss Equation is an empirical equation designed for the computation of long-term average soil loss in agricultural fields [3]. This equation was developed for detachment capacity limited erosion in fields with negligible curvature and no deposition [3] [15].

The RUSLE3D uses the same factorial approach employed by the USLE and RUSLE empirical equation but the $L S$ topographical factor evaluation was modified for complex topographic conditions. Indeed, the RUSLE3D incorporates 


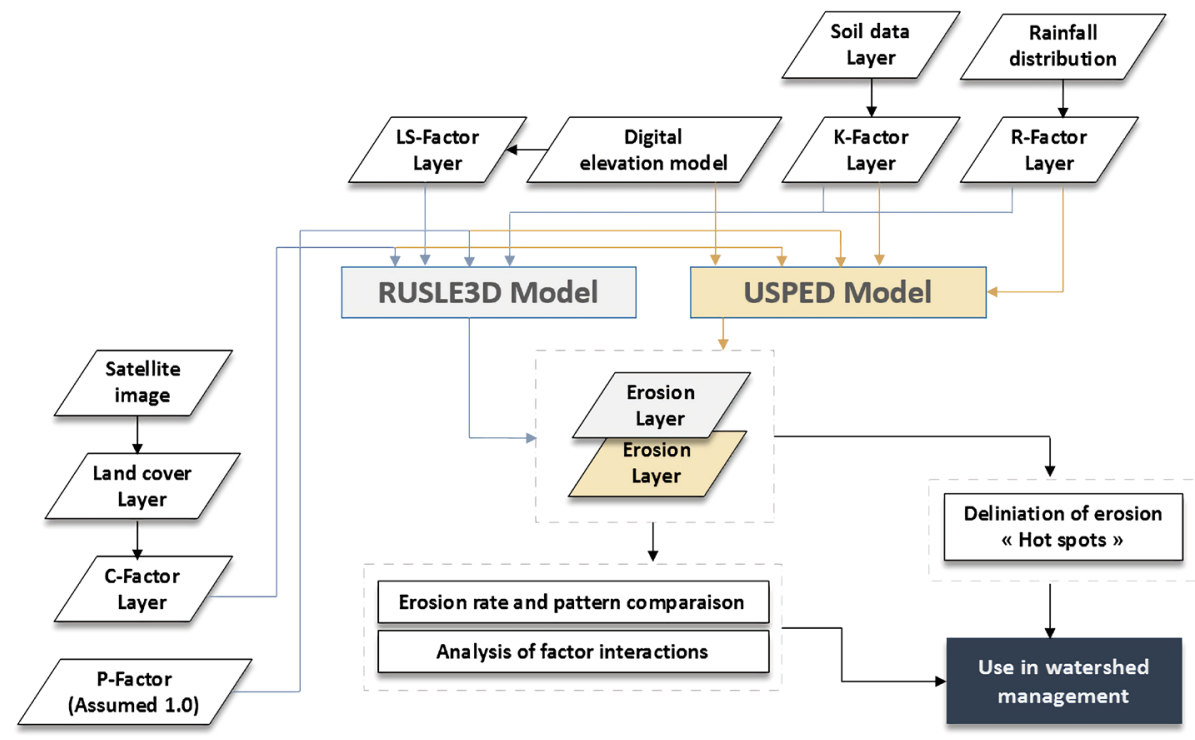

Figure 2. GIS-based methodology used in soil erosion assessment.

the impact of flow convergence taking into account the upslope contributing area in the $L S$ factor evaluation. It also differs by evaluating the erosion as the change in sediment transport capacity. The RUSLE3D model includes irregular hillsides integrating a wide spectrum of hillside convexities and concavities and it incorporates the upstream contribution area for the determination of the $L S$ factor.

The RUSLE3D Equation (1) calculates potential average soil loss $(A)$ as follows:

$$
A(r)=R * K * L S(r) * C * P
$$

where: $A(r)\left(\mathrm{t} \cdot \mathrm{ha}^{-1} \cdot \mathrm{y}^{-1}\right)$ is the average soil loss per year of a grid cell, i.e., at a point $r$ (geographic location of grid cell), $R\left(\mathrm{mt} \cdot \mathrm{ha} \cdot \mathrm{cm}^{-1}\right.$ ) is the rainfall intensity factor, $K\left(\mathrm{t} \cdot \mathrm{ha}^{-1}\right.$ per unit $R$ ) is the soil erodibility factor, $L S(r)$ (dimensionless) is the topographic (length-slope) factor at a grid cell $(r), C$ (dimensionless) is the land cover factor and $P$ (dimensionless) is the soil conservation or prevention practices factor.

The $L S$ factor is calculated as the product of slope length and slope steepness factors. The slope length was replaced by the up-slope contributing area per unit width of cell spacing $A(r)\left(\mathrm{m}^{2} \cdot \mathrm{m}^{-1}\right)$ in RUSLE-3D [8]. The modified $L S$ factor of a grid cell or at a point $r=(x, y)$ is calculated as in (2):

$$
L S(r)=(m+1)[A(r) / 22.13] m \sin [\beta(r) / 0.09] n
$$

where $\beta(r)$ is the land surface slope in degrees, $m$ and $n$ are constants equal to 0.6 and 1.3 .

With USPED, the erosion/deposition rate is estimated as the change in sediment flow rate expressed by the divergence in sediment flow [7] [8]. It assumes, as in (3), that the sediment flow rate $q s(r)$ corresponds to the sediment transport capacity $T c(r)$ : 


$$
q s(r)=T c(r)=K t(r) q(r) m \sin b(r) n
$$

where: $b(r)(\mathrm{deg})$ is slope, $q(r)$ is water flow rate $\left(\mathrm{m}^{3} \cdot \mathrm{m}^{-1} \cdot \mathrm{s}^{-1}\right), K t(r)$ is transportability coefficient, which is dependent on soil and cover; $m, n$ are constants that vary according to type of flow and soil properties. For overland flow the constants are usually set to $m=1.6, n=1.3$ [16].

Equation (4) as stated by Mitasova [17], assumes water flow can be expresses as a function of the upslope contributing area per unit contour width $A s(r)$ $\left(\mathrm{m}^{2} \cdot \mathrm{m}^{-1}\right)$ and the uniform rainfall intensity $i\left(\mathrm{~m} \cdot \mathrm{s}^{-1}\right)$ (note: approximation by upslope area neglects the change in flow velocity due to cover):

$$
q(r)=A(r) i
$$

No experimental work was performed to derive parameters needed for USPED, therefore we use the USLE or RUSLE parameters to incorporate the approximate impact of soil and cover and obtain at least a relative estimate of net erosion and deposition. The USPED model assumes, as in (5), that we can estimate sediment flow at sediment transport capacity as:

$$
T=R * K * C * P * A m(\sin b) n
$$

where $R=i m, K^{\star} C^{\star} P=K t$ and $L S=A m(\sin b) n$, and $m=n=1$ for prevailing sheet erosion.

Then $E D$ the net erosion/deposition is estimated as in (6):

$$
E D=\mathrm{d}(T \cos a) / \mathrm{d} x+\mathrm{d}(T \sin a) / \mathrm{d} y
$$

where $a(\mathrm{deg})$ is aspect of the terrain surface.

Foster [18] emphasized that caution should be used when interpreting the results because the USLE parameters were developed for simple plane fields and detachment limited erosion therefore to obtain accurate quantitative predictions for complex terrain conditions they need to be re-calibrated. Nevertheless, this model has been used in various studies [7] [19] [20] which found out that USPED-predicted erosion-deposition patterns correspond well with actual field observations.

The datasets used for the implementation of the two soil erosion models are summarized in Table 1 .

In purpose of models calibration and since the last bathymetrical campaign of

\begin{tabular}{|c|c|}
\hline Datasets & Description \\
\hline DTM & Raster format with $30 \mathrm{~m}$ spatial resolution (USGS data). \\
\hline Landsat 7 ETM+ & One scene acquired on 13/07/2014, with $30 \mathrm{~m}$ spatial resolution (USGS data). \\
\hline Rainfall data & $\begin{array}{l}\text { Daily rainfall data between } 2008 \text { and } 2014 \text { from Swat Global Weather data } \\
\text { (extrapolated point data with } 1 \mathrm{~km} \text { resolution). }\end{array}$ \\
\hline Lithologic map & Vector format [13]. \\
\hline
\end{tabular}
the M.B.A.K. dam reservoir was conducted by 2014, all the extracted temporal data variables were similarly limited to 2014 .

Table 1. Dataset collected and used in this study. 
The soil use and management factor $(C)$ was determined by using a Landsat satellite image (7 ETM+), from USGS data. The image was georeferenced with ground control points, and the NDVI was determined. The NDVI was then used to obtain a new image of a rescaled $C$ factor $C(r)$, as per the following Equation (7), [21]:

$$
C(r)=[(-\mathrm{NDVI}+1 / 2)]
$$

Considering the nonexistence of conservation practices in the watershed, the unit value of 1.0 was attributed to the $P$ factor.

The resulting specific degradation values of both models were compared with the erosion rates results obtained by a previous study done by Amil [14]. This earlier study was based on solid inputs quantification through a sedimentological sampling throughout the Nekor watershed.

\section{Results and Discussion}

The average annual soil loss in the Nekor watershed was computed with both the RUSLE3D and USPED by overlaying in ArcGIS the five factor grids with a uniform spatial resolution of $30 \mathrm{~m}$. The average annual soil erosion rates (RUSLE3D) and the average annual soil erosion/deposition rates (USPED) were estimated on a pixel basis, and then the relative maps were derived (Figure 3; Figure 4).

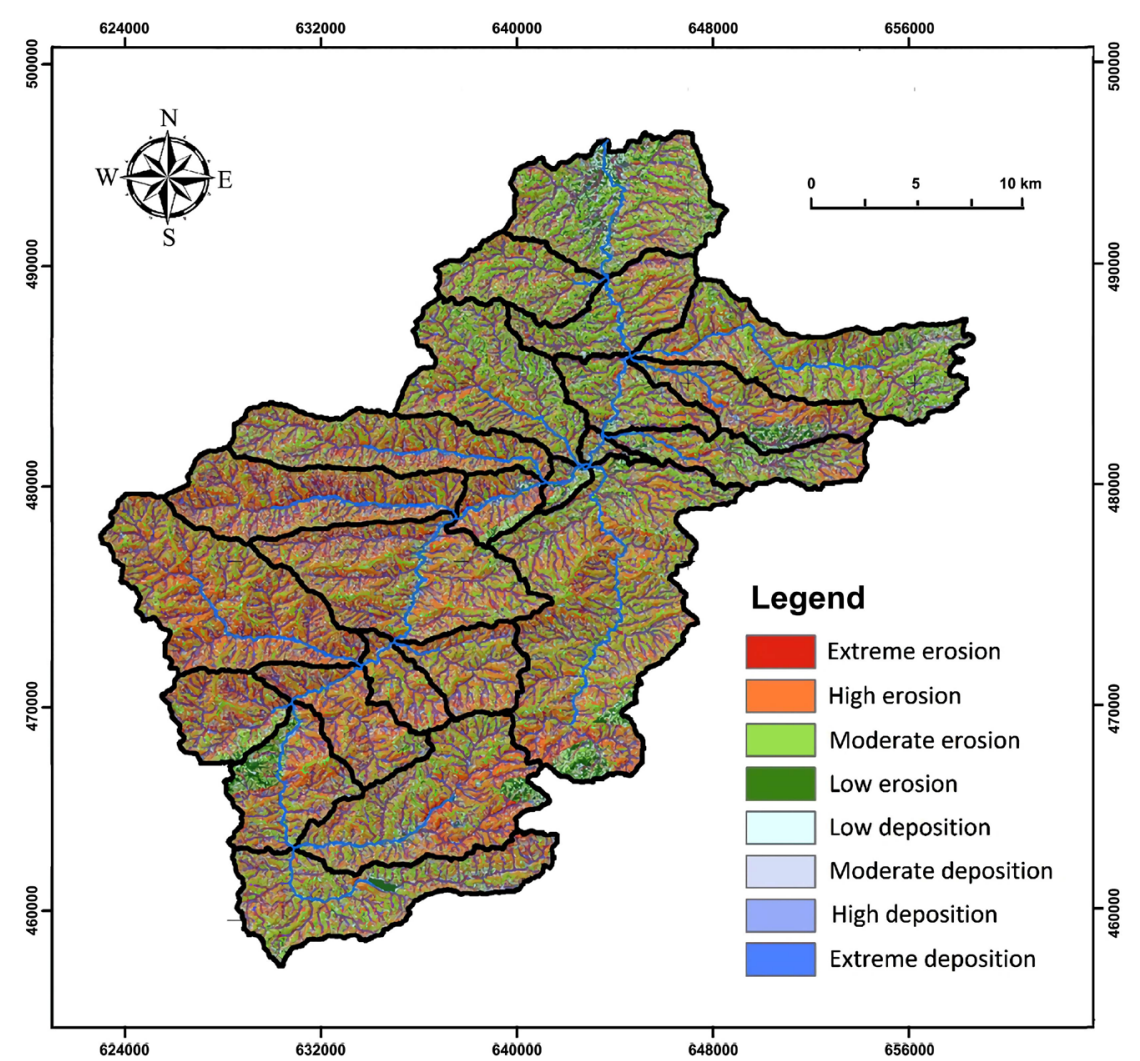

Figure 3. Spatial distribution of soil erosion and deposition rates within the Nekor watershed, computed with USPED and derived from ancillary data and remote sensing products with GIS application. 


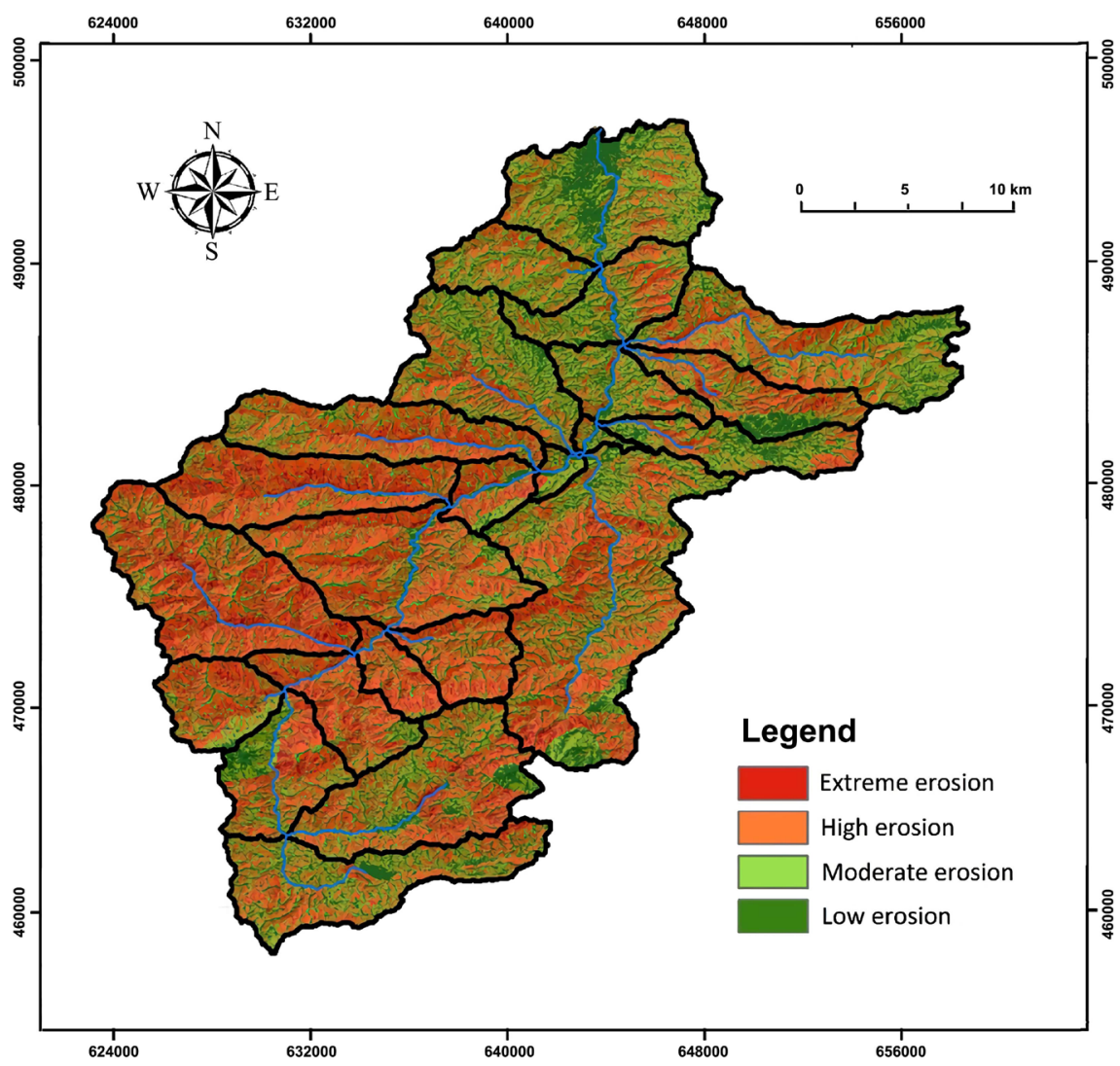

Figure 4. Spatial distribution of soil erosion rates within the Nekor watershed, computed with RUSLE3D and derived from ancillary data and remote sensing products with GIS application application.

According to the final results, the mean annual soil loss computed with the RUSLE3D is $60.77 \mathrm{t} \cdot \mathrm{ha}^{-1} \cdot \mathrm{year}^{-1}$, while the mean annual net soil erosion rate computed with the USPED is $65.68 \mathrm{t} \cdot \mathrm{ha}^{-1} \cdot \mathrm{year}^{-1}$. The mean annual deposition rate computed with USPED is $38 \mathrm{t} \cdot \mathrm{ha}^{-1} \cdot \mathrm{year}^{-1}$.

The application of the two models confirmed the results coming from previous soil erosion studies accomplished by Amil [14] based on sediment flow rate measurements and Lahlou [13], which estimate annual sediment yield in Nekor basin between 50 and $70 \mathrm{t} \cdot \mathrm{ha}^{-1} \cdot \mathrm{year}^{-1}$.

Our research pointed out the important impact of each factor into the soil loss process. Actually, the application of both models on our study area showed the preponderant importance of topography and the vegetation cover on the ablation rates.

The output data allowed us to assess the basin surface percentage for each class of soil erosion with both models (Table 2). As a result of the RUSLE3D application, about the $73 \%$ of the Nekor basin ranges between moderate and extreme risks of erosion, while the $27 \%$ results at low risk of erosion. According to the USPED estimation, about the $50 \%$ of the basin ranges between moderate and extreme risks of erosion, while the remaining 50\% ranges between low erosion and various degrees of soil deposition. 
Table 2. Percentage of basin surface for each class of soil erosion for both models.

\begin{tabular}{ccc}
\hline & \multicolumn{2}{c}{ Basin surface } \\
\cline { 2 - 3 } Classes $\left(\mathrm{t}^{\left.-h^{-1} \cdot \mathrm{year}^{-1}\right)}\right.$ & RUSLE3D & USPED \\
\hline Extreme erosion $(<-200)$ & 4 & $6 \%$ \\
High erosion $(-50--200)$ & 38 & $9 \%$ \\
Moderate erosion $(-10--50)$ & 31 & 35 \\
Low erosion $(0--10)$ & 27 & 27 \\
Low deposition $(0-10)$ & & 6 \\
Moderate deposition $(10-50)$ & & 8 \\
High deposition $(50-200)$ & & 2 \\
Extreme deposition $(>200)$ & 100 & 6 \\
Total & & 100 \\
\hline
\end{tabular}

Both models similarly show high erosive activity in the western and southwestern shores of the Nekor Basin where the slopes are the steepest. Moreover, on the eastern shore (average slopes) while RUSLE 3D maintains the same high erosion trend, USPED rather shows moderate erosion activity accompanied by moderate sediment deposition areas.

This result suggests that the anti-erosive management structures should be primarily more concentrated and oriented towards the left Nekor sub-basins, in order to limit siltation phenomenon of the downstream MBAK dam.

The difference observed between RUSLE3D and USPED results of soil loss percentages distribution may be due to the fact that RUSLE3D is a detachment capacity limited model and represents soil loss without considering soil deposition. Conversely, USPED is a transport capacity limited model and it has the ability to identify the spatial distribution of both erosion and deposition rates for a constant state of overland flow with uniform rainfall-excess conditions. It would seem that USPED is able to better distinguish between the areas characterized by erosion and the areas where deposition can occur. Thus, according to [22], as long as any of the factors in the RUSLE3D equation is greater than zero, some erosion rate will be predicted even if the actual erosion is null.

It is almost hard in such a study (i.e. at a large scale watershed as Nekor river basin) to attain the spatial validation of soil erosion rates due to the deficiency of direct measurements. The most applied method is founded on sediment catchments in closed systems, such as lakes and artificial reservoirs (e.g. dams) [23] [24] [25] [26]. The validation of soil erosion estimation at a large reservoir scale using catchment silting values allows testing the reliability and the predictive capacity of such estimations, although some possible sources of uncertainty should be considered in reservoir silting data (e.g. potential error coming from reservoir grain size sediments variation, bathymetric surveys and raw data interpolation, catching efficiency) [27]. Though, these uncertainties lead to minor errors on the global silting data [28]. 
Table 3. Comparison between the RUSLE3D and USPED computed amounts of soil erosion over the Nekor river basin and M.B.A.K. dam silting value.

\begin{tabular}{cccc}
\hline & Measured silting data & Rusle3D & Usped $^{\mathrm{a}}$ \\
\hline Nekor basin & $1.13 \times 10^{6}\left(\mathrm{t} \cdot \mathrm{year}^{-1}\right)$ & $4.8 \times 10^{6}\left(\mathrm{t} \cdot \mathrm{year}^{-1}\right)$ & $5.1 \times 10^{6}\left(\mathrm{t} \cdot \mathrm{year}^{-1}\right)$ \\
Sediment Delivery Ratio & - & $23(\%)$ & $22(\%)$ \\
\hline
\end{tabular}

${ }^{\mathrm{a}}$ Only erosion values were accounted.

Thus, the RUSLE3D and USPED supposed estimations were compared with the M.B.A.K. dam silting value, supplied by a regional authority responsible for its management (Regional Directorate of Water Management) (Table 3). The comparison suggests that over $22 \%$ of sediments eroded in the Nekor watershed are transported until the outlet's basin. With the USPED slightly closer to the measured silting data than the RUSLE3D, the approximate match of those values (i.e. $22 \%$ and 23\%) indicates that the RUSLE3D and USPED can be considered reliable in quantifying the amount of soil erosion at the watershed scale.

The output of both models confirms previous studies results conducted by Lahlou [13] and Amil [14] and calls the attention to the importance of lithology and topography, as they represent the leading drivers of soil erosion in mostly western areas (i.e. higher slopes) of the basin. In gentle areas, vegetation covers were more relevant factors.

\section{Conclusions}

The application of both RUSLE3D and USPED models suggests priority to the left Nekor sub-basins for erosion control structures implementation.

Both models showed their feasibility to estimate the spatial distribution of soil loss at the watershed scale. The results pointed out the influence of lithology and topography factors as they represent the primary drivers of soil erosion in mostly western areas with higher slopes of the basin. Vegetation cover was more relevant factor in flat areas.

The analysis and quantification of this phenomenon contribute to an understanding of applicability of those empirical models over large areas, which calls for a well-distributed and adequate monitoring network to achieve a proper validation of the spatial patterns of erosion and deposition.

\section{Acknowledgements}

The authors are very grateful to the Regional Directorate of Water and Forestry for their help and hospitality during fieldwork. The authors would also like to extend their gratitude to MASCC and ALMIRA projects and to Hassan II Academy of Science and Technology for their funding support to GISEC project. Useful comments from anonymous reviewers greatly improved the text.

\section{Conflicts of Interest}

The authors declare no conflicts of interest regarding the publication of this paper. 


\section{References}

[1] Ministère Chargé des Eaux et Forêts (1999) The Moroccan National Development Plan of Watersheds. Department of Soil, Water and Forests Conservation, Rabat.

[2] Heusch, B. (1970) L'érosion du PRE-RIF. Une étude Quantitative de l'érosion Hydraulique dans les Collines Marneuses du Pré-Rif Occidental (Maroc). Annales Recherche Forestière au Maroc, 12, 9-176.

[3] Wischmeier, W. and Smith, D. (1978) Predicting Rainfall Erosion Losses: A Guide to Con-Servation Planning. U.S. Department of Agriculture, Washington DC.

[4] Williams, J. (1975) Sediment Routing for Agricultural Watersheds. Journal of the American Water Resources Association, 11, 965-974. https://doi.org/10.1111/j.1752-1688.1975.tb01817.x

[5] Renard, K., Foster, G., Weesies, G., McCool, D. and Yoder, D. (1997) Predicting Soil Erosion by Water: A Guide to Conservation Planning with the Revised Universal Soil Loss Equation (RUSLE). U.S. Department of Agriculture, Washington DC.

[6] Mitasova, H. and Mitas, L. (1999) Modeling Soil Detachment with RUSLE 3D Using GIS. University of Illinois at Urbana-Champaign, Champaign, Urbana.

[7] Mitas, L. and Mitasova, H. (1998) Distributed Soil Erosion Simulation for Effective Erosion Prevention. Water Resources Research, 34, 505-516. https://doi.org/10.1029/97WR03347

[8] Mitasova, H., Hofierka, J., Zlocha, M. and Iverson, L. (1996) Modelling Topographic Potential for Erosion and Deposition Using GIS. International Journal of Geographical Information Systems, 10, 629-641. https://doi.org/10.1080/02693799608902101

[9] Mitasova, H. and Mitas, L. (1999) Erosion/Deposition Modeling with USPED Using GIS. University of Illinois at Urbana-Champaign, Champaign, Urbana.

[10] Cerdan, O., Souchère, V., Lecomte, V., Couturier, A. and LeBissonnais, Y. (2001) Incorporating Soil Surface Crusting Processes in an Expert-Based Runoff and Erosion Model: Sealing and Transfer by Runoff and Erosion related to Agricultural Management. Catena, 46, 189-205. https://doi.org/10.1016/S0341-8162(01)00166-7

[11] Kirkby, M., Irvine, B., Jones, R., Govers, G. and PESERA Team (2008) The PESERA Coarse Scale Erosion Model for Europe. Model Rationale and Implementation. $E u$ ropean Journal of Soil Science, 59, 1293-1306. https://doi.org/10.1111/j.1365-2389.2008.01072.x

[12] Merritt, W., Letcher, R. and Jakeman, A. (2003) A Review of Erosion and Sediment Transport Models. Environmental Modelling \& Software, 18, 761-799. https://doi.org/10.1016/S1364-8152(03)00078-1

[13] Lahlou, A. (1990) Envasement du Barrage Mohamed Ben Abdelkrim Al Khattabi et lutte Antiérosive du Bassin Versant Montagneux Situe à l'amont. International Association of Hydrological Sciences Publication, Wallingford, 243-252.

[14] Mourad, A. (1992) Bassin Versant du Nekor: Recherche des Zones Sources D'envasement de la Retenue du Barrage M.B.A el Khettabi (Maroc), Dakar: Ph.D. Thesis, Cheikh Anta Diop University, Dakar, 8-9.

[15] Renard, G., Foster, G., Weesies, G. and Porter, J. (1991) RUSLE: Revised Universal Soil Loss Equation. Journal of Soil and Water Conservation, 46, 30-33.

[16] Foster, G. and Wischmeier, W. (1974) Evaluating Irregular Slopes for Soil Loss Prediction. Transactions of the ASAE, 17, 305-309.

https://doi.org/10.13031/2013.36846 
[17] Mitasova, H., Barton, M., Ullah, I., Hofierka, J. and Harmon, R. (2013) 3.9 GIS-Based Soil Erosion Modeling. In: Shroder, J.F., Ed., Treatise on Geomorphology, Academic Press, San Diego. https://doi.org/10.1016/B978-0-12-374739-6.00052-X

[18] Foster, G. (1990) Process-Based Modelling of Soil Erosion by Water on Agricultural Land, in Soil Erosion on Agricultural Land. John Wiley \& Sons Ltd., Chichester, 429-445.

[19] Pistocchi, A., Cassani, G. and Zani, O. (2002) Use of the USPED Model for Mapping Soil Erosion and Managing Best Land Conservation Practices. 1st International Congress on Environmental Modelling and Software, Lugano, 24-27 June 2002, 163-168.

[20] Zaluski, M., Consort, J. and Antonioli, S. (2003) Soil Erosion and Deposition Modeling in ArcGIS. Business and Industry Symposium, 108-113.

[21] Durigon, V.I., Carvalho, D., Antunes, M., Oliveira, P. and Fernandes, M. (2014) NDVI Time Series for Monitoring RUSLE Cover Management Factor in a Tropical Watershed. International Journal of Remote Sensing, 35, 441-453. https://doi.org/10.1080/01431161.2013.871081

[22] Knijff, J.V.D., Jones, R. and Montanarella, L. (1999) Soil Erosion Risk Assessment in Italy. European Commission, EUR 19022 EN, 52 p.

[23] Van Rompaey, A., Bazzoffi, P., Jones, R. and Montanarella, L. (2005) Modeling Sediment Yields in Italian Catchments. Geomorphology, 65, 157-169. https://doi.org/10.1016/j.geomorph.2004.08.006

[24] Krasa, J., Dostal, T., Rompaey, A.V., Vaska, J. and Vrana, K. (2005) Reservoirs' Siltation Measurments and Sediment Transport Assessment in the Czech Republic, the Vrchlice Catchment Study. Catena, 64, 348-362. https://doi.org/10.1016/j.catena.2005.08.015

[25] De Vente, J.D., Poesen, J., Bazzoff, P., Rompaey, A. and Verstraeten, G. (2006) Predicting Catchment Sediment Yield in Mediterranean Environments: The Importance of Sediment Sources and Connectivity in Italian Drainage Basins. Earth Surface Processes and Landforms, 31, 1017-1034.

[26] De Vente, J., Poesen, J., Verstraeten, G., Rompaey, A.V. and Govers, G. (2008) Spatially Distributed Modelling of Soil Erosion and Sediment Yield at Regional Scales in Spain. Global and Planetary Change, 60, 393-415. https://doi.org/10.1016/j.gloplacha.2007.05.002

[27] Lazzari, M., Gioia, D., Piccarreta, M., Danese, M. and Lanorte, A. (2015) Sediment Yield and Erosion Rate Estimation in the Mountain Catchments of the Camastra Artificial Reservoir (Southern Italy): A Comparison between Different Empirical. CATENA, 127, 323-339. https://doi.org/10.1016/j.catena.2014.11.021

[28] Snyder, N., Rubin, C.A.D.M, Childs, J., Curtis, J., Flint, L. and Wright, S. (2004) Estimating Accumulation Rates and Physical Properties of Sediment behind a Dam: Englebright Lake, Yuba River, Northern California. Water Resources Research, 40, W11301. https://doi.org/10.1029/2004WR003279 